\title{
Langerhans Cell Histiocytosis in Children: A Single Center Experience from Turkey
}

\author{
Huseyin TOKGOZ, Umran CALISKAN \\ Necmettin Erbakan University, Meram Faculty of Medicine, \\ Department of Pediatric Haematology, Konya, TURKEY
}

\begin{abstract}
The aim of the study is to present the experience of children diagnosed with Langerhans cell histiocytosis (LCH) at our center. Medical records of children with $\mathrm{LCH}$ were screened in terms of gender, age at diagnosis, clinical findings, risk groups, treatment modalities and outcome. The study included 9 patients with a median age of 22 months. The most common clinical finding was bone lesions $(\% 88,8)$, followed by hepatosplenomegaly (\%44.4), lymphadenopathy (\%44.4), seborrheic dermatitis $(33,3 \%)$ and jaundice $(33.3 \%)$. Of the 9 patients, 3 (33.3\%) had single system disease [1 (11.1\%) had unifocal while 2 (22.2\%) had multifocal disease], 6 (66.6\%) had multisystem disease [2 (22.2\%) had risk organ negative and 4 (44.4\%) had risk organ positive]. At the end of the 6th week of therapy, 5 patients (55.5\%) had all the dead children had better response, $1(11.1 \%)$ had an intermediate response while $3(33.3 \%)$ had worse response. In terms of outcome, 5 (55\%) patients were in complete remission, 3 (33\%) patients were dead, and 1 patient was lost to follow up. All dead children had multisystem disease with risk organ involvement and were worse responders at the 6th week of therapy. In children with $\mathrm{LCH}$, the most important factors determining prognosis were risk organ involvement, multisystem disease and response at 6th week of treatment. New treatment modalities such as new drugs or stem cell transplantation are required for children with risk organ positive multisystem disease, as the prognosis remains poor.
\end{abstract}

Keywords: Langerhans cell histiocytosis, Child

\section{ÖZET}

\section{Çocuklarda Langerhans Hücreli Histiyositoz: Türkiye'den Tek Merkez Deneyimi}

Bu çalışmanın amacı, merkezimizde Langerhans hücreli histiyositoz $(\mathrm{LCH})$ tanısı alan çocuklar ile ilgili deneyimlerimizi sunmaktadır. LCH tanıı çocukların tıbbi kayıtları, hastaların cinsiyeti, tanı yaşı, klinik bulgular, risk grupları, tedavi rejimleri ve gidişat açısından değerlendirilmek üzere incelendi. Medyan yaşı 22 ay olan 9 hasta çalışmaya dâhil edildi. En sık görülen klinik bulgu kemik lezyonlarıydı (\%88.8). Bunu hepatosplenomegali (\%44.4), lenfadenopati (\%44.4), sarllik (\%33.3), seboreik dermatit (\%33.3) takip etmekte idi. Dokuz olgudan üçünde (\%33.3) tek sistem tutulumu (1 tanesi tek odaklı, 2 tanesi çok odaklı), 6'sında $(\% 66,6)$ çoklu sistem tutulumu [2 tanesi (\%22.2) risk organ tutulumsuz, 4 tanesi (\%44.4) risk organ tutulumlu] mevcuttu. 6 haftalık tedavinin sonunda; 5 hastada (\%55.5) iyi cevap, 1 hastada (\%11.1) orta cevap ve 3 (\%33.3) hastada kötü cevap alındı. Gidişat açısından değerlendirildiğinde; 5 hasta (55.5\%) tam remisyona girmiş, 3 (\%33.3) hasta ölmüş, bir hasta takipten çıkmıştı. Ölen çocukların hepsi çoklu sistem tutulumlu risk grubunda olan ve 6 haftalık tedaviye kötü tedavi cevabı olan hastalardı. LCH'li çocuklarda prognozu belirleyen en önemli faktörler; risk organ tutulumu, çoklu sistem tutulumu ve 6. hafta tedavisine olan cevaptır. Risk organ tutulumu olan hastalarda prognoz kötü olduğu için yeni ilaçlar veya kök hücre nakli gibi yeni tedavi yaklaşımlarına ihtiyaç vardır.

Anahtar Kelimeler: Langerhans hücreli histiyositoz, Çocuk 


\section{INTRODUCTION}

Langerhans cell histiocytosis ( $\mathrm{LCH})$ is a rare nonmalignant disease characterized by accumulation and proliferation of clonal dendritic cells, unpredictable course, and extreme clinical heterogeneity. The clinical manifestations of LCH vary from single bone disease to fatal disseminated form. ${ }^{1,2}$ Categorizing patients based on the number and location of lesions and the presence of organ involvement were shown to be useful in predicting prognosis and determining therapy. ${ }^{3}$ Single system LCH (SS-LCH) disease which usually affects bone, less frequently affects skin, and rarely affects the lymph nodes, lungs or central nervous system (CNS), accounts for approximately two thirds of pediatric cases. ${ }^{3}$ Involvement of two or more organ systems, referred to as multisystem LCH (MS$\mathrm{LCH}$ ), accounts for the remaining one third of cases. In about half of MS-LCH cases, risk organs (i.e., the liver, spleen, and hematopoietic system) are affected. Involvement of the risk organs adversely affects prognosis.

We analyzed our single center experience of children with LCH. The purpose of the study is therefore to raise awareness of the disease and to highlight the clinical findings that should make the paediatrician or primary care-givers suspect the diagnosis, as well update on current thinking regarding management of the various and diverse manifestations of this disease.

\section{PATIENTS AND METHODS}

The patients diagnosed with $\mathrm{LCH}$ between the years of 2000 and 2015 were enrolled the study. The patients were diagnosed and treated at Meram Medical Faculty, Department of Pediatric Hematology. The study was approved by the local ethics committee.

The patients were evaluated respectively for the age at diagnosis, gender, clinical classification, risk groups, medical treatment and outcome of disease. Clinical data were obtained through a review of medical records. Criteria for histological diagnosis were based on the recommendations of the Histiocyte Society. ${ }^{4}$ Definitive diagnosis was established for all patients by demonstrating pathologic Langerhans cells which stained CD1a and S100, as well as typical clinical findings.
Patients were retrospectively classified ${ }^{5}$ as follows; Single system (SS) disease (unifocal or multifocal) and Multisystem (MS) disease (RO positive or RO negative).

Patients were classified into 3 categories, according to the response observed at the 6th week of therapy ${ }^{4}$ as follows; "Better" response (continued regression or total resolution of disease); Intermediate response (stable disease or regression in some sites with new lesions in others); Lack of response ("worse", disease progression).

Reactivation was defined as the appearance of new lesions or organ dysfunction after remaining stable for three months. ${ }^{6}$ The criteria of hepatic involvement ${ }^{4}$ were hepatic enlargement $>3 \mathrm{~cm}$ below costal margin in the midclavicular line, and/or hypoproteinemia, hypoalbuminemia $<25 \mathrm{~g} / \mathrm{L}$ not due to other causes, and/or histopatological diagnosis.

\section{RESULTS}

For the period of 2000-2015, 9 patients with $\mathrm{LCH}$ were followed up, 7 of which were males $(77.7 \%)$, 2 of which were females (22.2\%). Age at diagnosis varied from 4 months to 16 years old (median 22 months). The general epidemiological data of patients are summarized in Table 1. The median time to follow up, time of death and time of relapse were 30 months, 20 months and 12 months, respectively.

The most frequent clinical manifestation at diagnosis was bone lesions in $88.8 \%$ of cases, followed by lymphadenopathy $(44.4 \%)$ and hepatosplenomegaly $(44.4 \%)$ (Table 2$)$. In relation to the stage of disease, of the 9 patients with LCH, $1(11.1 \%)$ had SS unifocal disease, $2(22.2 \%)$ had SS multifocal disease, 2 (22.2\%) had RO-negative MS disease, and 4 (44.4\%) had RO-positive MS disease (Table 1).

Prednisolon and vinblastine (VBL) were administered in initial treatment, as proposed by the Histiocyte Society. ${ }^{4}$ At the end of the 6th week of therapy, 5 patients $(55.5 \%)$ had better response, 1 (11.1\%) had an intermediate response and $3(33.3 \%)$ had worse response (Table 1).

In term of outcome, 5 patients were in complete remission, 3 patients died. One patient was lost to follow up. All of the dead children were in ROpositive MS disease and worse responder at the 6th week of therapy. 


\begin{tabular}{|c|c|}
\hline \multicolumn{2}{|l|}{ Characteristics } \\
\hline Age at diagnosis & 4 months -16 years \\
\hline Median & 22 months \\
\hline Follow up time & 2 months- 9 years \\
\hline Median & 30 months \\
\hline Gender & n (\%) \\
\hline Male & $7(77)$ \\
\hline Female & 2 (23) \\
\hline \multicolumn{2}{|l|}{ Clinical classification } \\
\hline Single sistem disease-unifocal & $1(11.1)$ \\
\hline Single sistem disease-multifocal & $2(22.2)$ \\
\hline Multisystem disease-without risk organ involvement & $2(22.2)$ \\
\hline Multisystem disease-with risk organ involvement & $4(44.4)$ \\
\hline \multicolumn{2}{|l|}{ Response at the 6 th week of therapy } \\
\hline Better & $5(55.5)$ \\
\hline Intermediate & $1(11.1)$ \\
\hline Worse & $3(33.3)$ \\
\hline \multicolumn{2}{|l|}{ Clinical status at time of analysis } \\
\hline In remission, still under folllow-up & $3(33.3)$ \\
\hline In remission, discharged & $2(22.2)$ \\
\hline Lost to follow-up & $1(11.1)$ \\
\hline Recurrence & $3(33.3)$ \\
\hline Death & $3(33.3)$ \\
\hline
\end{tabular}

Reactivation was observed in $3(33.3 \%)$ patients, 1 had multifocal bone disease and 2 had RO-positive MS disease. The patient who had multifocal bone disease was treated with VBL, prednisolon plus mercaptopurine. This therapy resulted in good response at the end of 12th month with only one small osteolytic lesion on the scalp. After discontinuation of therapy, this lesion was in a stable condition for 24 months. The other two MS risk patients were not responding to the combination therapy (VBL, Prednisolon, Mercaptopurine, metothrexate) or salvage therapy with 2-chlorodeoxy adenosine (2CDA) combined with cytarabine. One patient died, and the other is alive. Two of 6 patients (33.3\%) who survived had one or more permanent sequelae findings. One patient with RO-positive MS disease had central diabetes insipitus (CDI) and vertebra plana. In this patient, pituitary stalk thickening and loss of the physiological high-intensity signal of the posterior pituitary lobe on T1-weighted mag- netic resonance imaging (MRI) were demonstrated. One patient with multifocal bone disease had one stable lesion on the scalp.

Hepatic involvement was observed in 4 (44.4\%) of 9 patients. Three of 4 patients died. Two of three patients who died had developed sclerosing cholangitis. One of four patients is alive without hepatic dysfunction, but with CDI and vertebra plana. In relation to bone involvement; 3 patients had single bone involvement (mandible, hard palate, coxae), 2 had orbital bone involvement, one had vertebra plana, 4 had cranial bone involvement.

Five $(55.5 \%)$ of 9 patients were diagnosed before the age of 2 (before two years of age). Four of them had MS risk disease, 3 of whom died. One of them had multifocal bone disease.

Bone marrow and lung involvements were established in two patients $(22.3 \%)$ respectively. Both of them were died. Hematopoietic stem cell trans- 
Table 2. Clinical manifestations of patients with Langerhans cell histiocytosis

\begin{tabular}{|ll|}
\hline Clinical manifestation & $\mathbf{n}(\mathbf{\%})$ \\
\hline Osteolytic lesions & $8(88.8)$ \\
Lymphadenopathy & $4(44.4)$ \\
Mucocutaneous lesions & \\
$\quad$ Seborrheic dermatitis & \\
$\quad$ Gum or palatal involvement & $3(33.3)$ \\
$\quad$ Loose of teeth & $1(11.1)$ \\
Fever & $1(11.1)$ \\
Hepatomegaly & \\
$\quad$ Sclerosing colangitis & $4(44.4)$ \\
Splenomegaly & $2(22.2)$ \\
Jaundice & $4(44.4)$ \\
Diabetes insipitus & $3(33.3)$ \\
Vertebra plana & $1(11.1)$ \\
Exophthalmia & $1(11.1)$ \\
Lung involvement & $1(11.1)$ \\
Hematopoietic system involvement & $2(22.2)$ \\
& $2(22.2)$ \\
& \\
\hline
\end{tabular}

plantation was planned to refractory and recurrent patients. However, HLA matched sibling donor or unrelated donor could not be found for these patients.

\section{DISCUSSION}

$\mathrm{LCH}$ is diagnosed most often in the age group between 0 and 3 years, with most cases of MS disease beginning before the age of 2. MS disease, especially RO-positive type, is more common in infants. ${ }^{1}$ In our study, majority of children were less than 3 years of age at diagnosis (median age 22 months). Five of 9 patients were infants and four of them had RO-positive disease. LCH appears to be more common in boys than girls. 1 Our 7 of 9 patients were male, consistent with literature.

Children with LCH may represent a wide spectrum of clinical presentation. In our study, clinical findings of patients had similar the previous reports. ${ }^{1,7}$ The most common clinical presentation is bone involvement ( $88.8 \%$ ), followed by lymphadenopathy $(44.4 \%)$, hepatosplenomegaly $(44.4 \%)$, jaundice (33.4\%) and skin involvement (33.3\%) (Table 2).
In pediatric patients, the skull is the most commonly affected bone followed by the spine, extremities, ribs and pelvic bone. ${ }^{8} \mathrm{X}$-Ray typically demonstrates osteolytic lesions with sharp margins. If $\mathrm{LCH}$ is only localized to the bone, the clinical course is usually benign. However, it can result into critical or irreversible symptoms due to localization of lesions, such as visual disturbances, exophthalmia, hearing loss, loss of teeth and spinal paralysis. ${ }^{1}$ Our study also demonstrated that the skull was the most commonly (88.8\%) affected bone. Unusual sites of bone involvement observed in two patients included hard palate and mandible. Vertebral lesions without soft tissue extension are not regarded as "special site" lesions. ${ }^{4}$ One of our patients had vertebra plana without soft tissue extension. Another patient had involvement of the hard palate leading to lost of teeths.

In children, pulmonary involvement is usually a part of MS disease but not an independent prognostic variable. ${ }^{9}$ The two patients with pulmonary involvement had RO positive MS disease. Both of them died. It may be due to other critical involvements of risk organs such as liver and hematopoietic system.

The disease outcome and severity are heterogeneous in patients with MS-LCH, therefore treatment stratification and risk-adapted treatment are obligatory. ${ }^{10}$ The risk for mortality can be predicted based on involvement of 'risk organs' (e.g. hematopoietic system, spleen, and/or liver) at diagnosis and on response to initial therapy. In term of outcome, $3(33.3 \%)$ children died. All of them were in ROpositive MS disease and worse responder at the 6th week of therapy, consistent with literature.

In MS LCH, the main aims of treatment are to increase survival and to reduce reactivations. Systemic chemotherapy with VBL and corticosteroid for 6-12 months is the most commonly used regimen in MS LCH. Three clinical trials (LCH-I, -II, and -III) have tested this regimen and showed that it provides an increased survival rate in risk organnegative patients, even in infants. ${ }^{5,11}$ However, despite this treatment, the mortality rates of ROpositive patients remain high at $16-38 \% .^{5,11}$ In our study, patients without risk organ involvement had excellent outcome, but 3 of 4 patients with ROpositive MS disease had died. However, this high 
mortality rate may be related to the small number of cases.

Sclerosing cholangitis has been reported and may lead to secondary biliary cirrhosis, portal hypertension and liver failure. ${ }^{12}$ The etiology is not understood. The only successful treatment has been liver transplantation. Two of our patients who had sclerosing cholangitis died. The presence of cholangitis may be a poor prognostic factor for the $\mathrm{LCH}$ patients.

In $50 \%$ of patients with MS disease and $25 \%$ of all patients with $\mathrm{LCH}$, the involvement of pituitary gland and/or hypothalamus was observed. ${ }^{13}$ The most common clinical manifestation is CDI. It occurs more frequently in patients with craniofacial bone lesions, ear, eye and/or oral lesions ${ }^{14}$ and thus these lesions are known as CNS-risk lesions. Systemic chemotherapy rarely cures CDI. One of our patients with RO-positive MS disease had CDI, demonstrated by pituitary stalk thickening and loss of the physiological high-intensity signal of the posterior pituitary lobe on T1-weighted magnetic resonance images. Systemic chemotherapy resulted in good response but CDI persisted, consistent with literature.

Those without involvement of risk organs, as well as those with involvement of risk organs who respond to standard initial therapy, have a superior chance of long-term survival. ${ }^{4}$ A combination of prednisolone and VBL has been verified to be effective treatment with minimal toxicity as initial therapy. Patients with risk organ involvement who do not respond within the first 6 weeks of therapy - especially those with evident clinical progression - have a negative prognosis. ${ }^{5,15}$ Early therapy intensification is justified for such patients. Patients with multifocal bone disease are known to have an excellent prognosis (survival of $100 \%$ ), but have a high tendency for reactivation (30-50\%) and permanent outcomes. ${ }^{4}$ In this study, all of the patients had initially used PRED and VBL. In addition, high risk patients received methothrexate, $500 \mathrm{mg} /$ $\mathrm{m}^{2} /$ dose on week $1,3,5$.

Presently, optimal second-line options for patients diagnosed with persisting or relapsing $\mathrm{LCH}$ in nonrisk organs have not yet been identified. Previously used treatments that have demonstrated success include the intralesional injection of steroids ${ }^{16}$; the combination of vincristine, prednisone, and cytarabine; and 2-chlorodeoxyadenosine as a single agent. ${ }^{17}$ In our study, 3 of 9 patients with MS risk disease were treated with 2-CDA combined ARA$\mathrm{C}$ as second line therapy. It has been reported that the combined therapy of 2-CDA and ARA-C may be useful for patients with refractory or recurrent disease. ${ }^{18}$ All of the three cases died. The unresponsiveness to 2-CDA and ARA-C treatment for our patients may be related to advanced stage and recurrent disease.

The mortality rate of patients with SS disease or without risk-organ involvement is less than $5 \%{ }^{1}$ However children with MS disease and with riskorgan involvement have a worse prognosis despite intensive treatment and their mortality is reported to be $10-50 \% .^{1}$ In our study, all deaths occurred among patients with RO positive MS disease at diagnosis. Overall survival was significantly lower for patients with MS disease when compared to those with SS disease. ${ }^{19}$ It has been shown that therapy prolongation of such patients improves the outcome. ${ }^{11}$ In our study, the therapy was prolonged in patients with MS disease and multifocal bone disease. Hematopoietic stem cell transplantation may be a therapeutic option of patients with refractory and recurrent disease. ${ }^{20}$ However, HLA matched donor could not be found for our patients.

Our study is a retrospective evaluation of 9 children with $\mathrm{LCH}$, managed in a tertiary center in Turkey, within the period of 2000-2015. Clinical manifestations had largely mimicked previous reports. Through we had lesser number of patients, our experience of 9 patients confirms that the prognosis is good in patients with SS or RO-negative MS disease. However, children with high risk features who do not respond rapidly to standard treatment have a poor prognosis. For this group of patients, intensive chemotherapy, alternative agents such as 2-CDA, clofarabine, cytarabine, BRAF inhibitors and HSCT should be considered. ${ }^{16}$ In addition, it is possible to make transplantation from an HLA mismatched donor in patients with a bad clinical course.

\section{REFERENCES}

1. Morimoto $A$, On $Y$, Shioda $Y$, et al. Recent advances in Langerhans cell histiocytosis. Pediatr Int 56: 451-461, 2014. 
2. Monsereenusorn C, Rodriguez-Galindo C. Clinical Characteristics and Treatment of Langerhans Cell Histiocytosis. Hematol Oncol Clin North Am. 29: 853-873, 2015.

3. Degar BA, Fleming MD, Rollins BJ, Rodriguez-Galindo C. Histiocytoses. In: Nathan and Oski's Hematology and Oncology of Infancy and Childhood. Orkin SH, Fisher DE, Ginsburg D, et al. 8th edition. Elsevier Saunders, Philadelphia, 2015: 2100-2122.

4. Minkov M, Grois N, McClain K, et al. Langerhans cell histiocytosis. Histiocyte society Evaluation and Treatment Guideliness. 2009 (https://www.histiocytesociety.org/document. doc?id=290. Access date 01/14/2016).

5. Gadner H, Grois N, Potschger U, et al. Improved outcome in multisystem Langerhans cell histiocytosis is associated with therapy intensification. Blood 111: 2556-2562, 2008.

6. Pollono D, Rey G, Latella A, et al. Reactivation and risk of sequelae in Langerhans cell histiocytosis. Pediatr Blood Cancer 48: 696-699, 2007.

7. Singh T, Satheesh CT, Appaji L, et al. Langerhan's cell histiocytosis: A single institutional experience. Indian J Med Paediatr Oncol 31: 51-53, 2010.

8. Imashuku S, Kinugawa N, Matsuzaki A, et al. Langerhans cell histiocytosis with multifocal bone lesions: comparative clinical features between single and multi-systems. Int J Hematol 90: 506-512, 2009.

9. Ronceray L, Potschger U, Janka G, et al. Pulmonary involvement in pediatric-onset multisystem Langerhans cell histiocytosis: effect on course and outcome. J Pediatr 161: 129-133, 2012.

10. Minkov M. Multisystem Langerhans cell histiocytosis in children: current treatment and future directions. Paediatr Drugs 13: 75-86, 2011.

11. Gadner H, Minkov M, Grois N, et al. Therapy prolongation improves outcome in multisystem Langerhans cell histiocytosis. Blood 121: 5006-5014, 2013.

12. Lanzkowsky P. Manual of Pediatric Hematology and Oncology. Fifth edition. London, Elsevier, 2011: 567-599.

13. Grois N, Fahrner B, Arceci RJ, et al. Central nervous system disease in Langerhans cell histiocytosis. J Pediatr 156: 873881, 2010.

14. Grois $\mathrm{N}$, Potschger $\mathrm{U}$, Prosch $\mathrm{H}$, et al. Risk factors for diabetes insipidus in langerhans cell histiocytosis. Pediatr Blood Cancer 46: 228-233, 2006.
15. Minkov M, Grois N, Heitger A, et al. Response to initial treatment of multisystem Langerhans cell histiocytosis: an important prognostic indicator. Med Pediatr Oncol 39: 581-585, 2002.

16. Allen CE, Ladisch S, McClain KL. How I treat Langerhans cell histiocytosis. Blood 126: 26-35, 2015.

17. Stine KC, Saylors RL, Saccente S, et al. Efficacy of continuous infusion 2-CDA (cladribine) in pediatric patients with Langerhans cell histiocytosis. Pediatr Blood Cancer 43: 81 84, 2004.

18. Bernard F, Thomas $C$, Bertrand $Y$, et al. Multi-centre pilot study of 2-chlorodeoxyadenosine and cytosine arabinoside combined chemotherapy in refractory Langerhans cell histiocytosis with haematological dysfunction. Eur J Cancer 41: 2682-2689, 2005.

19. Babeto LT, de Oliveira BM, de Castro LP, et al. Langerhans cell histiocytosis: 37 cases in a single brazilian institution. Rev Bras Hematol Hemoter 33: 353-357, 2011.

20. Kesik V, Citak C, Kismet E, et al. Hematopoietic stem cell transplantation in Langerhans cell histiocytosis: case report and review of the literature. Pediatr Transplant 13: 371-374, 2009.

\section{Corresspondence}

Dr. Huseyin TOKGÖZ

Necmettin Erbakan Üniversitesi

Meram Tip Fakültesi

Pediatrik Hematoloji Anabilim Dali

Akyokus Mevkii

Meram, KONYA / TURKEY

Tel: (+90-332) 2237886

e-mail: drhuseyintokgoz@hotmail.com 